\title{
Adopting Micro Insurance Models in Providing Pension Benefits to Nigerian Rural Dwellers
}

\author{
T. A. NGEREBO-A (Corresponding author) \\ Senior Lecturer, Banking \& Finance Department \\ Faculty of Management Sciences \\ Rivers State University of Science \& Technology \\ Nkpolu - Port Harcourt, Nigeria \\ Tel: 234-803-338-7003 E-mail: oniminp2002@yahoo.com
}

\author{
Sunday C. Nwite \\ (Lecturer, Department of Banking and Finance \\ Ebonyi State University, Abakaliki, Nigeria
}

Tel: 234-803-774-3134 E-mail: nwitewhite2006@yahoo.com

Received: Sep. 28, 2012 Accepted: October 18, 2012 Published: December 31, 2012 doi:10.5296/bms.v3i2.2935 URL: http://dx.doi.org/10.5296/bms.v3i2.2935

\begin{abstract}
Employees are faced with unpredictable retirement life, and therefore dream of guaranteed income inflow during retirement. Acquisition of shares and buildings for commercial purposes seems to be the easy antidote to this challenge, until the introduction of the Contributory Pension Scheme in 2004 by the Nigerian government. The scheme legally guarantees $50 \%$ lump payment upon retirement and the spreading of the payment of the remaining $50 \%$ of the total retirement benefit on regular basis throughout the life span of the retiree. The latter $50 \%$ could be used to buy savings account or annuity contract. However, most retirees are faced with the problem of irregularly paid incomes, which usually are very low. This paper x-rays the expected impact of micro insurance scheme on providing retirement benefits to the rural dwellers.
\end{abstract}

It was found that Micro Insurance Scheme will help to provide retirement benefits through 
collection and invest of savings made payable to the rural dwellers on retirement. Therefore, it was concluded that micro insurance scheme is the preferred way of providing pension benefits to the rural dwellers upon retirement. Hence, we recommend that Nigerian governments should encourage micro insurance pension for rural dwellers, mostly the artisans, through effective enlightenment measures.

Keywords: Micro insurance, Pension benefits, Rural dwellers, Retirement benefits 


\section{Introduction}

2012, Vol. 3, No. 2

Pension scheme in Nigeria is one of the things inherited form the colonialists, so is as old as the nation's history. Pension scheme benefits are post-employment benefits available to retirees to enable them cope with their various responsibilities till death. The sole aim is for the workers (potential retirees or pensioners) to give their full concentration and their very best within the useful age their employments. But this type of benefits was originally only for those who are working in public and civil service. It was a guarantee against old age for public servants, as against the experience of private sector employees and rural dwellers (mostly farmers, fishermen and artisans) whose old age was guaranteed with serious uncertain future and poverty unto death. Of this latter group of income-earners, the retirement life experience of rural dwellers appears more bleak and worrisome. This is why most rural dwellers depend almost solely on their children for living. As far as these people were concerned, provisioning for old age was abstract except saving in the form of educating their children. On the contrary, retirees especially from public or government employments reasonably maintained themselves and met their family responsibilities because of their monthly pension incomes.

There existed, therefore, a need to bridge the gap between the standard of living of these two sets of people, hence the introduction of Micro Insurance Scheme, whereby the rural dwellers (and other low income earners) contribute money and are paid a lump sum of 50\% of the accumulated contribution on retirement and the remaining $50 \%$ will be used to provide regular pension till death.

This work therefore tries to know the possibility of operating micro insurance scheme and its expected impact on the rural dwellers and other low income earners.

\section{The Concept of Micro Insurance}

Micro insurance means different things to different people. It is seen as an insurance which involves small amounts of money contributed to a pool of funds at periodic intervals for a long time. The total contribution of each contributor to the common pool of funds will be made available to the contributor at old age (Ogunleye et al, 2006). It has been defined as the insurance used in protection of low income earning households against special perils in exchange for regular premium payment proportionate to the likelihood and cost. Micro insurance is one of several tools to manage risks of low income earners (Barrientos and Hulme, 2008). It has been explained differently as a risk pooling instrument for protection of low income rural dwellers, insurance with small benefits, insurance involving low levels of premium, insurance for persons working in the informal economy, etc. (Ranoldink, 2009). It can also be seen as a community based financing arrangement including community health funds, mutual health organization, rural health insurance revolving drugs fund and community-involvement in user-free management. It is used to determine the economic level of a society (Mnwette, 2008).

However, for the purpose of this research work, micro insurance is defined as insurance that is accessed by low income population, provided by a variety of different entities, but run in accordance with generally acceptable insurance practices which should include the 
core insurance principles. This means that the management of micro insurance scheme can be based on insurance principles and funded by premiums. It does not include government social welfare, emergency assistance provided by government in respect of natural disaster, flood disaster etc, because benefits are not paid out of the pool, funds that are managed based on insurance and risk principles.

\section{Historical Development of Micro Insurance}

Micro insurance is not a new phenomenon in most markets, including emerging markets. There are a variety of micro insurance scheme such as the mutual health care schemes, and funeral contributory schemes, which may have started many years ago but have remained informal.

Formal insurance was founded on the idea of protecting specified segments of the society against their major risks. For instance, most of the prominent large insurance companies began in Europe and North America in the 1800s as protection schemes among factory workers and farmers. Over the years, however, efforts to prevent fraud and misuse have resulted in the issuance of policies, rules and regulation and requirements that might not be effective or appropriate for the low income earners. In some cases, efforts to maximize shareholders' returns have led insurers away from their original clientele in search of more profitable customers (Sebstad, 2003).

Micro insurance has evolved from community-based and other local initiatives, to be promoted by local and foreign donors. In some cases, bilateral and multi lateral donors have provided technical and financial assistance to micro-insurers, and even promoted conceptual discussions on micro insurance. However, some valuable lessons can be drawn from micro insurance, which has a longer history and a broader global reach (McCord, 2006). The growth and success of micro insurance has been responsible for creating a delivery channel to help regulate insurers' target of the low income segment in an efficient manner (McCord, 2006).

\section{Reasons for Micro Insurance Scheme}

The reasons for micro insurance scheme are listed below according to Nwite (2008).

1) To provide protection for people or rural dwellers in the informal economy and their families who live in a risky environment which are exposed to perils.

2) TO provide insurance policy for the rural dwellers against illness, accidental death, disability, loss of property due to theft, fire, agricultural losses etc.

3) To help the low-income households to manage their risk that is beyond their capacity.

4) Micro finance also assist to maintain a sense of financial confidence even in the face of significant vulnerability.

5) To provide source of livelihood for the members of the family after the death of the breadwinner of such family. At the death of the breadwinner if the breadwinner has obtained micro insurance policy, the members of the family will not suffer at the death of the breadwinner. 
6) To be able to encourage the rural dwellers and low-income households to save and provide credit services to themselves.

7) To get the rural dwellers educated about the need for insurance: Micro insurance can also be used to educate the rural dwellers about the importance of insurance.

\section{Expected Role of Micro Insurance in Providing Pension Benefits to Rural Dwellers}

Like any programme, micro insurance plays some catalytic roles in providing different types of pension-related benefits. Some of the roles are:

1) It will help to cater for old age: It will encourage the rural dwellers to make provision for retirement from service thereby making them to plan for their old age, just the way the formal pension scheme benefits employees (Mmbor, 2003; Zupan, 2003).

2) It will enable rural dwellers to imbibe the habit of savings against any unforeseen exigencies of life in an informal manner, as against the formal pension scheme (Kuti, 2003).

3) It will protect families from financial hardship they might run into after retirement from service (Payne, 1993).

4) It will reduce the dependence on government, as contributors will secure their old age by depending on insurance firms rather than depending on government.

5) It will reduce the level of poverty in the country: Since one's old age has been catered for, the poverty level in the economy will be reduced.

6) Since the pension benefit is being done by the micro insurance, it will be affordable for the rural dwellers compared to any other insurance company.

\section{Conceptual and Historical Development of Pension Scheme in Nigeria}

The purpose of pension is to provide retirement income for individuals in their old age. In industrialized world pension scheme is very important because they believe that it gives care and support to the elderly ones (Nwite, 2004). It provides long-term funds for industrial and investment activities.

The ongoing increase in longevity is making retirement income a crucial aspect of lifetime revenues for individuals, while the proportion of pension assets in household's net worth is growing. Companies are increasingly sponsoring pension schemes and pension funds are assuming crucial aspect of corporate finance. For financial institutions, the growth of pension is heightening the challenge of competition for all institutions in the field of asset management, while the particular roles of banks as traditional intermediaries is being encroached upon by other institution.

Historically, Pension Scheme in Nigeria dates back to 1951 when the first Pension Act was enacted, but was subsequently replaced by the Pension Decree 102 of 1979.

In 1961, the National Provident Fund was established by the Act of parliament, to provide income loss protection for employees as required by the International Labour Organization (ILO) convention of 1952. Only private sector employees were to make monthly 
contribution of $6 \%$ of their basic salary subject to a maximum of $£ 8.00$ to be contributed in equal proportion of $£ 4.00$ each by the employer and the employees.

In 1993 an Act of Parliament established and mandated the Nigerian Social Insurance Trust fund (NSITF) to set up Pension Fund Administrators (PFA) to manage the accumulated pension funds of NSITF from contributors for a period of five years.

Meanwhile, the Pension Decree of 1979 established a scheme for all public servants except those who were on temporary or contract employment, with The Office of Establishments and Pensions as a Trustee for the public scheme. The benefit of this Act was the making of a lump sum (gratuity) and a regular payment (pension) for life to qualified former employees. Those who retire after ten years of service were entitled to a gratuity of 100 percent of their annual salary only. But this was later amended to five years for gratuity. However, with the irregularities occasioned by the scheme coupled with new socio-economic challenges and innovations, the need to keep up with modern trend and changes called for the conception and birth of a new pension scheme established by the Pension Reform Act 2004. This Act introduced the contributory pension scheme that mandated employers of labour and employees both in the private and the public sectors to make a contribution of 7.5\% each (by the employer and employee) of the employee's total monthly emolument for the period of service. Private organizations employing five or more employees were to participate in the scheme mandatorily.

\section{Problems of Pension Scheme in Nigeria}

1) Illiteracy: This is the major problem facing pension scheme. Most of the skilled manual workers are illiterate to the benefits of pension scheme and they might not like to contribute to the scheme.

2) Inadequate of public awareness: This is also another problem because the manual workers don't know the meaning and existence of pension scheme and not educated enough of the benefits and the risk for participating.

3) Inflation: Inflation has really affected pension scheme in that it has discouraged people from saving for the retirement.

4) Mismanagement of fund: The workers might be afraid of saving in pension scheme because of fear of fund not adequately managed by the authority concerned or misappropriation.

5) Corruption: Most people would not be encouraged to put their funds in pension scheme because of fear of embezzlement of their funds by the mangers of the fund. A lot of past experiences unveil this fear.

\section{The Prospects of the Scheme}

The prospect of the pension scheme are stated below according to Nwite (2004)

1) Provision of security: With pension fund arrangement, rural dwellers are highly secured from any risk that may occur for not planning against their old age. 
2) Restoration of confidence: This is one of the prospects of effective management of pension scheme that is people/rural dwellers are reassured that saving is worthwhile and the pension they invest in will be there when they retire. The setting up a pension protection fund will enhance the prospects of the scheme since this fund guarantees the safety of contributions even if the micro insurance firms are liquidated.

3) Propensity to save: conscientious implementation of the scheme will encourage people to save against their retirement. This therefore creates good atmosphere for savings element in individual.

4) Reduces social burden: Adequate implementation of the scheme will help to reduce government budgetary provision to meet some social responsibilities especially to the aged population.

5) Reduction of over dependent on government: It will also help to reduce dependence on the government to pay pension adequately without shortcomings. When one's old age has been catered for, it reduces the dependence on the government.

6) Reduction of fraud: Adequate implementation of the scheme will also reduce the fraud element in the pension schemes and in the society. Pension scheme administrators, custodians and natural pension commission as well as the Pension Act will help to reduce pension fraud and money can be easily released when the worker is retired.

\section{The Challenges of the Scheme}

Some of the challenges faced are:

1) Nigerian/rural dwellers are not yet developed for such practice. All these are the various views of people, even the discrimination in payment.

2) Poor accounting record management: Record keeping in Nigerian organizations, big and small, is very problematic. Records are either unprofessionally kept or kept contrary to known principles. The operation of the scheme faces the challenge of standardized principles and the dearth of professionals.

3) Corruption: This pandemic has eroded trust and could pose a big challenge to the acceptance, subscription to and smooth operation of the scheme. This will be a major challenge because a one-off corruptly sourced income, if prudently invested will dwarf the accumulated fund obtainable from micro insurance scheme. Besides, with the high turnover of financial institutions due from distress occasioned by misappropriations of entrusted funds, potential operators (rural dwellers) will definitely be skeptical to participate in the scheme.

4) Inflation: This affects the saving habit of retirees because it devalues the amount saved from the retirement planning. Inflation has been difficult to contain in Nigeria implicitly except on the published reports made to portray the economy as performing. Infact, inflation has thrown more low income earners below the poverty line.

5) Lack of public awareness: Most people are not aware of the bleak future awaiting them in say 20 or 30 years time when they retire from service. Some believe that the government should 
make provision for their increasing future responsibilities, and with the increases the cost of living, people fail to save against the future.

\section{Conclusions}

In the course of writing this work, the following conclusions were made;

1) Pension scheme creates good atmosphere for savings

2) Micro insurance is an important tool to reduce risk for people with low income especially where the premium is attractively low.

3) There are a lot of challenges facing pension scheme in Nigeria.

4) Inflation adversely affects pension scheme.

5) With pension scheme the rural dwellers are well secured after retirement or at old age.

\section{Recommendations}

a) Government should ensure that the contribution made by the rural dwellers to the scheme is well secured.

b) Government should also ensure constitutionality of the pension Act.

c) Government, through its regulatory agency, should also ensure that the premium charged is affordable.

\section{References}

Aneke, J. I. (1998). Principles and Practice of Insurance. Enugu: Saps Nig. Inc.

Asian Development Bank. (2009). Micro Insurance Sector Development. Report on Technical Assistance to the Democratic Socialist Republic of Sri Lanka, Manila.

Bodie, Z. (1990). "Pension As Retirement Benefit". Journal of Economic Literature", 28(1).

Chizea, B. E. (2007, Feb. 23.). "Can Contributory Pension Scheme Solve our Problems Finding” Financial Standard.

Chukwu, A. (2006, July 6). "The Activities of the Contributory Pension Scheme". Financial Standard.

Chukwulozie, O. E. (2003, December 25 $\left.5^{\text {th }}\right)$. "Administration Reforms of Nigerian Pension Scheme" Guardian.

Churchill, C. (Ed) (2006) Protecting the Poor A Micro Insurance Compendum", Geneva Switzerland; International Labour Office.

Cohen M., \& Sebstand, A (2006) The Demand for Micro Insurance, [Online] Available: Http://www.microfinancegateway.org/content /articles/details/400 99on 20th April, 2009.

Diego E. (2004) "Marketing of Pension Project under Contributory Pension era problems and Prospects". 
Dorr, D., \& Jacquier, C. (1999). "Micro Insurance Extending Health Insurance to the Excluded" Internal Social Security Review, 52(1), 71-97. Geneva' ISSA http://dx.doi.org/10 1/11/1468-246x-00034

Helms, F. (2007). "Financial Risk Management Tools for the Poor". [Online] Available: http://www.microfinancegateway.org/content/articles/details/26598 on 18th April, 2009, P.7.

Hemming N., \& Richarie M. (1978). "Should Public Pension be funded”. IMF Working paper 98/35 (Washington D.C. International Monetary Fund).

Jacqier C., Ramm G., Marcadent P., \& Schmmt D. V. (2006). The Social Protection Perceptive on Micro Insuranc, [Online] Available: http://www.microfinancegateway.org/content/articles/details/26598 on 18th April, 2009.

Mnwetter, C. (2008). Micro Insurance Key to Protecting the Poor. [Online] Available: http://www.microfinancegateway.org/content /articles/details/26698 on 19th April, 2009.

Nwite S. C. (2005). "Pension Reform in Nigeria"; A Seminar paper presented for the Award of Associates number. The Certified pension Institute of Nigeria.

Ogunleye, B., Ngerebo, T. A., \& Adeyemi, F. (2006). "Reflecting on the Burden of Deposit Insurance." Journal of Banking and Investment, 1(2).

Oladele M. O. (2005, May $3^{\text {rd }}$ ). The Impact of Contributory Pension Scheme on The Ongoing Pension Problems. Guarandiaro.

Ranoldink F. (2009). Understanding Micro Insurance. [Online] Available: www.microfinancegateway.org on 20th April, 2009.

Reeve O. (1998). Pension Scheme and Administration Chartered Insurance Institute Service. London Page 1.

Reinhard D., \& Qureshi (2006). Making Insurance Work in Africa. A Report Presented on The International Conference Micro Insurance, Cape Town, South Africa.

Sebstad Y. (2003). What is the role of Micro Insurance? [Online] Available: http://www.microfinancegateway.org/content/articles/details/26598 on 18th March, 2009.

Vijah M., \& Basix (2005). Micro Insurance Enhancing the Outreach and Sustainability of Risk Mitigation Services for the Poor Access Finance, World Bank Newsletter, P.13.

Wish, V (ed) (2006). How Micro Insurance Serves the Poor, Allianz Knowledge [Online] Available: http://www.microfinancegateway.org/content /articles/details/26598 on 18th April, 2009.

\section{Web References}

Contributory Pension. (2008) (Online access in 28 Feb http.//www.benefitfundpensions:con/history.html)

Contributory Pension Scheme. (2008) (Online access on May 28 
http://www.pensionsporter.co.uk/statepensioncfm)

Contributory Pension Scheme. (2008) (Online access on May 28 http://www.admin.com.ac.uk.reporter/1999-2000/weekly/5818/13.html).

Contributory Pension Scheme. (2008) (Online access on May 28 http://wwwbasisguide/retirement/pension/oapcontributoryhtml.

Contributory Pension Scheme. (2008) (Online access on May 28 http://www/whisinfo.org/aboutabis.htm).

Pension Reform Act. (2004). http://www.axisis-govile/retirement/pension/ oap contributory html. Pension on Reform Act 2004

NSITF. (2002). http://oasisgoo.ie/retirement/pension/oapcountributory.html 